\title{
Evaluation of Subclinical Left Ventricular Systolic Dysfunction Using Two Dimensional Speckle Tracking Echocardiography in Patients with Psoriasis Attia Morsy Skokr ${ }^{1}$, Ahmed Rashad Elshahed ${ }^{2}$, Youssef Fathy Nosir ${ }^{1}$, Muhammad Abdullah AbdelSallam ${ }^{1}$ \\ Departments of ${ }^{1}$ Cardiology and ${ }^{2}$ Dermatology, \\ Faculty of Medicine, Al-Azhar University, Cairo, Egypt \\ *Corresponding author: Muhammad Abdullah AbdelSallam, Mobile:(+20) 01008851030, Email: crazy.doctor1990@gmail.com
}

\begin{abstract}
Background: dermatologists as well as cardiologists have been studying cardiologic complications of psoriasis for many years. The reason for an increased cardiovascular morbidity in psoriasis seems to be the chronic systemic inflammatory process. Aim of the Work: to evaluate and detect subclinical LV dysfunction by 2D speckle tracking echocardiography in psoriatic patients. Patients and Methods: we selected 100 psoriatic patients (group 1) subclassified them into two equal subgroups; subgroup (1a) involved 50 psoriatic patients recently diagnosed and on topical treatment and subgroup (1b) included 50 psoriatic patients on systemic treatment. The study also included 30 apparently healthy individuals' age and sex matched with the patients' group represents the control group.

Results: in comparison with healthy subjects, patients with psoriasis were found to have lower LV function using 2D speckle tracking. The 2-D speckle method appears to be useful in the detection of LV systolic dysfunction in patients with psoriasis 'A statistically significant difference was found between sub-groups according to duration of Disease (years), psoriatic arthritis, PASI score and high sensitive CRP. Conclusion: the 2- D speckle tracking method appears to be useful in the detection of LV systolic dysfunction in patients with psoriasis. Subclinical left ventricular systolic dysfunction in psoriasis is linked with the inflammatory up-regulation, and enhanced pro-fibrotic activity may be involved in this process. These putative mechanisms may be responsible for the observed higher incidence of heart failure in this disease condition and should be considered as a potential target for preventive and therapeutic measures. Keywords: subclinical LV dysfunction, 2D speckle tracking echocardiography, psoriasis.
\end{abstract}

\section{INTRODUCTION}

It is increasingly recognized that psoriasis is also associated with an increased risk for cardiovascular (CV) disease which cannot be explained by traditional $\mathrm{CV}$ risk factors. Some reports have emphasized that the development of $\mathrm{CV}$ risk factors and major adverse cardiac outcomes such as myocardial infarction, stroke, and $\mathrm{CV}$ mortality are increased, especially in patients with severe psoriasis ${ }^{(\mathbf{1})}$.

It is generally believed that psoriasis does not impair left ventricular (LV) systolic function (2). However, one publication has revealed subclinical $\mathrm{LV}$ dysfunction to be more frequent in psoriatic arthritis (PsA) ${ }^{(2)}$.

The systemic inflammatory response in psoriasis is regulated by T helper 1 and T helper 17 lymphocytes, which play a key role in its pathogenesis, leading to endothelial damage with premature progression to atherosclerosis ${ }^{(3)}$.

A number of imaging techniques, including echocardiography, magnetic resonance imaging, and scintigraphy, have been used in the assessment of LV systolic function ${ }^{(4)}$.

Arterial stiffness has been identified as an independent prognostic factor for patients with $\mathrm{CV}$ disease (CVD) ${ }^{(5)}$. An increased pulse wave velocity (PWV), a noninvasive index of arterial stiffness, predicts $\mathrm{CV}$ events in different clinical conditions. Increased arterial stiffness negatively affects cardiac structure and function with systolic and diastolic abnormalities ${ }^{(6)}$. It seems likely that patients with psoriasis may display changes in the ECG that may be markers of risk of CVD and such ECG markers may then represent unmeasured confounders in previous studies of CVD risk in psoriasis ${ }^{(7)}$.

Ejection fraction (EF), tissue Doppler imaging (TDI), Doppler strain and, recently, speckle tracking echocardiography (STE) have been commonly used in the assessment of LV function ${ }^{(\mathbf{8})}$.

The EF is the most widely used index of LV function, but because of its visual component, the assessment of endocardial excursion is subjective and has high interobserver variability ${ }^{\left({ }^{(9)}\right.}$.

Two- dimensional strain imaging is a novel technique which assesses LV systolic functions more objectively and quantitatively and does not have the drawbacks of EF, TDI, and Doppler strain; thus, it has become more commonly used in recent years ${ }^{(\mathbf{8})}$.

\section{AIM OF THE WORK}

The purpose of this study is to evaluate subclinical left ventricular systolic dysfunction using two dimensional speckle tracking echocardiography in patients with psoriasis.

\section{PATIENTS AND METHODS}

This cross-sectional comparative study involved 100 psoriatic patients collected from the Dermatology clinic of Al-Azhar University Hospitals; the patients were screened for the study enrollment prospectively. The study was performed at Cardiology Department, Faculty of Medicine, Al-Azhar University at the period from October 2018 to June 2019. 


\section{Protocol Approval by Ethical Committee:}

Before the beginning of the study and in accordance with the local regulation followed, the protocol and all corresponding documents were declared for Ethical and Research approval by the Cardiology Department, Faculty of Medicine, AlAzhar University.

\section{I- Study design:}

\section{1) Type of the study:}

A cross-sectional comparative clinically controlled study in which we studied and evaluate subclinical left ventricular (LV) systolic dysfunction by $2 \mathrm{D}$ speckle tracking echocardiography in psoriatic patients in all selected patients and control.

\section{Patients:}

The patients were classified into two groups matched in age:

Group (1): Patients' group: 100 psoriatic patients. They were subclassified into two equal subgroups:

(a) Fifty psoriatic patients recently diagnosed and on topical treatment.

(b) Fifty psoriatic patients on systemic treatment.

Group (2): Thirty apparently healthy individuals' age and sex matched with the patients' group represent the control group.

\section{Inclusion criteria of the patients:}

The study included patients at any age, with psoriasis who do not have chronic or autoimmune diseases and are able to understand instructions and provide informed consent.

\section{Exclusion criteria:}

Known hypertensive, diabetic patients, documented ischemic heart disease, patients with any type of pulmonary hypertension, patients with congenital heart disease, atrial fibrillation (AF), patients with reduced $\mathrm{EF} \leq 50 \%$, poor image quality on echocardiographic window, significant comorbidities, patients with bad compliance, uncooperative patients, patients that refused the consent or the study or inability to give informed consent were excluded from the study.

\section{II- Technical Design:}

All patients were subjected to the following:

Personal history: name, age, sex, residence and occupation, past history: history of previous medical illness, history of previous drug intake, history of previous operations (PCI or CABG), History of smoking, present history: onset and duration of the disease, local and systemic drugs used, full general examination including cardiological, chest, and abdominal examination including, Blood pressure and pulse rate measurement, Both upper and lower limbs for edema, Head and neck examination, chest and abdominal examination, Urine analysis to detect significant proteinuria. Resting surface 12 leads ECG will be done for all patients to detect any arrhythmia specially $\mathrm{AF}$ and evidence of ischemia,
Echocardiography and ILocal dermatological examination.

\section{Echocardiographic examination:}

All patients were examined at rest in the left lateral decubitus position to obtain adequate images in different standard views.

Chamber quantification was performed in accordance with the recommendations of the American society of echocardiography and Assessment of the Right Heart in Adults ${ }^{(\mathbf{1 0})}$ respectively.

- Left ventricular end diastolic dimension (LVEDD): this will be done using long axis view long axis view with M-mode sampling and 2D.

- Left ventricular Ejection fraction (LVEF \%) will be determined using Simpson's biplane volumetry.

\section{Two- dimensional Speckle- tracking echo- cardiography (STE)}

Two- dimensional (2D) strain represents myocardial deformation from a $2 \mathrm{D}$ point of view. Negative strain represents shortening, while positive strain indicates thickening of a given myocardial segment. STE analysis using the commercially available automated function image technique was applied to apical long- axis slices (long- axis and two- chamber and four- chamber views) for assessment of LV global longitudinal strain (GLS).

The endocardial borders were traced in the endsystolic frame of the 2D images from each of the three apical views (each divided into six conventional segments). Speckles were tracked frame- by- frame throughout the LV wall until the software automatically approved the tracking for the six segments. Segments that failed to track were adjusted manually by the operator until the software approved them. GLS was calculated as the average longitudinal strain of all six segments of each of the three views (two- chamber, four- chamber and long- axis, i.e. as the mean strain of all 18 segments), GLS was according to Kocabay et al. ${ }^{(11)}$. We used reference values from Kocabay et al. ${ }^{(11)}$.

\section{Written informed consent:}

An approval of the study was obtained from AlAzhar University academic and ethical committee. Every patient signed an informed written consent for acceptance of the operation.

\section{III- Statistical Methods}

Data were collected in a master sheet, coded, entered and analyzed using both SPSS version 22 medical statistics software and Microsoft Excel v. 2013. For all tests done, the threshold of significance was fixed as 5\% level student t-test $(\mathrm{t})$ and the probability $(P$ value): $\mathrm{P}$ value of $>0.05$ indicates nonsignificant results, $P$ value of $<0.05$ indicates significant results, $\mathrm{P}$ value of $<0.01$ indicates highly significant results, $\mathrm{P}$ value of $<0.001$ indicates very highly significant results. 


\section{RESULTS}

Table (1): Comparison between patients and control according to baseline characteristics

\begin{tabular}{|c|c|c|c|c|}
\hline Demographic data & $\begin{array}{l}\text { Patient } \\
(n=100)\end{array}$ & $\begin{array}{c}\text { Control } \\
(n=30)\end{array}$ & $t / \chi^{2 \#}$ & p-value \\
\hline $\begin{array}{ll}\text { Age (years) } \\
\text { - } \quad \text { Mean } \pm \text { SD } \\
\text { - } \quad \text { Range } \\
\end{array}$ & $\begin{array}{c}30.97 \pm 5.99 \\
23-45\end{array}$ & $\begin{array}{c}29.30 \pm 7.84 \\
18-44\end{array}$ & 1.806 & 0.460 \\
\hline $\begin{array}{ll}\text { Sex } & \\
\text { - } & \text { Female } \\
\text { - } & \text { Male } \\
\end{array}$ & $\begin{array}{l}50(50.0 \%) \\
50(50.0 \%)\end{array}$ & $\begin{array}{l}15(50.0 \%) \\
15(50.0 \%)\end{array}$ & $0.000^{\#}$ & 1.000 \\
\hline \begin{tabular}{ll}
\multicolumn{2}{l}{ Smoker } \\
$-\quad$ No \\
$-\quad$ Yes \\
\end{tabular} & $\begin{array}{l}57(57.0 \%) \\
43(43.0 \%)\end{array}$ & $\begin{array}{l}15(50.0 \%) \\
15(50.0 \%)\end{array}$ & $0.458^{\#}$ & 0.499 \\
\hline $\begin{array}{ll}\text { BMI }\left[\mathbf{w t} /(\mathbf{h t})^{\wedge} \mathbf{2}\right] \\
\text { - } & \text { Mean } \pm \mathrm{SD} \\
\text { - } & \text { Range }\end{array}$ & $\begin{array}{c}24.05 \pm 3.25 \\
18-31\end{array}$ & $\begin{array}{c}23.37 \pm 2.28 \\
18-30\end{array}$ & 1.758 & 0.287 \\
\hline
\end{tabular}

$\mathrm{t}$ - Independent Sample t-test; ${ }^{\#} \mathrm{x}^{2}$ : Chi-square test; p-value >0.05 NS

This table shows no statistically significant difference between groups according to demographic data.

Table (2): Comparison between patients and control according to speckle

\begin{tabular}{|l|c|c|c|c|}
\hline Speckle & $\begin{array}{c}\text { Patient } \\
(\boldsymbol{n}=100)\end{array}$ & $\begin{array}{c}\text { Control } \\
(\boldsymbol{n}=30)\end{array}$ & t-test & p-value \\
\hline $\begin{array}{l}\text { Apical 3 chamber\% } \\
\text { Mean } \pm \text { SD }\end{array}$ & $\begin{array}{c}-17.86 \pm 2.52 \\
-24--14\end{array}$ & $\begin{array}{c}-21.27 \pm 1.51 \\
-25--19\end{array}$ & 49.163 & $<0.001^{* *}$ \\
Range & $-18.54 \pm 2.54$ & $-22.00 \pm 1.41$ & 50.527 & $<0.001^{* *}$ \\
\hline $\begin{array}{l}\text { Apical 4 chamber\% } \\
\text { Mean } \pm \text { SD }\end{array}$ & $-24.1--14$ & $-24--20$ & & \\
Range & $-17.74 \pm 2.87$ & $-21.47 \pm 1.41$ & 46.856 & $<0.001^{* *}$ \\
\hline $\begin{array}{l}\text { Apical 2 chamber\% } \\
\text { Mean } \pm \text { SD }\end{array}$ & $-23--11$ & $-24--19$ & \\
Range & & & \\
\hline
\end{tabular}

t-Independent Sample t-test; **p-value $<0.001 \mathrm{HS}$

This table shows statistically significant difference between groups according to Apical 3 chamber\%, Apical 4 chamber\% and Apical 2 chamber\%.

Table (3): Comparison between sub-group Topical Treatment, Systemic Treatment and Control according to demographic data

\begin{tabular}{|c|c|c|c|c|c|}
\hline $\begin{array}{l}\text { Demographic } \\
\text { data }\end{array}$ & $\begin{array}{l}\text { Group Ia: Topical } \\
\text { treatment }(n=50)\end{array}$ & $\begin{array}{c}\text { Group Ib: Systemic } \\
\text { treatment }(n=50)\end{array}$ & Control $(n=30)$ & $=/ \chi^{2 \#}$ & -value \\
\hline $\begin{array}{l}\text { Age (years) } \\
\text {-Mean } \pm \text { SD } \\
\text {-Range }\end{array}$ & $\begin{array}{c}28.02 \pm 3.88 \\
23-38\end{array}$ & $\begin{array}{l}31.92 \pm 5.05 \\
25-45\end{array}$ & $\begin{array}{c}27.30 \pm 7.84 \\
18-44\end{array}$ & .746 & 0.218 \\
\hline $\begin{array}{l}\text { Sex } \\
\text { - Female } \\
\text { - Male } \\
\end{array}$ & $\begin{array}{l}27(54.0 \%) \\
23(46.0 \%)\end{array}$ & $\begin{array}{l}23(46.0 \%) \\
27(54.0 \%) \\
\end{array}$ & $\begin{array}{l}15(50.0 \%) \\
15(50.0 \%)\end{array}$ & .640 & 0.726 \\
\hline $\begin{array}{l}\text { Smoker } \\
\text { - No } \\
\text { - Yes } \\
\end{array}$ & $\begin{array}{l}39(78.0 \%) \\
11(22.0 \%)\end{array}$ & $\begin{array}{l}18(36.0 \%) \\
32(64.0 \%) \\
\end{array}$ & $\begin{array}{l}15(50.0 \%) \\
15(50.0 \%)\end{array}$ & 3.305 & $\begin{array}{c}0.001 * \\
*\end{array}$ \\
\hline $\begin{array}{l}\mathbf{B M I}\left[\mathbf{w t} /(\mathbf{h t})^{\wedge} \mathbf{2}\right] \\
- \text { Mean } \pm \text { SD } \\
- \text { Range }\end{array}$ & $\begin{array}{c}22.52 \pm 2.64 \\
18-29 \\
\end{array}$ & $\begin{array}{c}23.58 \pm 3.10 \\
18-31 \\
\end{array}$ & $\begin{array}{c}21.37 \pm 2.28 \\
18-25 \\
\end{array}$ & .930 & 0.092 \\
\hline
\end{tabular}

F-One Way Analysis of Variance; $\# \chi^{2}$ : Chi-square test; $p$-value $>0.05 \mathrm{NS} ; * * \mathrm{p}$-value $<0.001$ (HS).

This table shows statistically significant difference between sub-groups according to smoker. 
Table (4): Comparison between sub-group Topical Treatment, Systemic Treatment and Control according to psoriasis

\begin{tabular}{|c|c|c|c|c|c|}
\hline Psoriasis & $\begin{array}{l}\text { Group Ia: Topical } \\
\text { treatment }(n=50)\end{array}$ & \begin{tabular}{|c|} 
Group Ib: \\
$\begin{array}{c}\text { Systemic treatment } \\
(n=50)\end{array}$ \\
\end{tabular} & $\begin{array}{c}\text { Control } \\
(n=30)\end{array}$ & $\mathbf{t} / \chi^{2 \#}$ & p-value \\
\hline $\begin{array}{l}\text { Disease duration }(\mathbf{y}) \\
\text { Mean } \pm \text { SD } \\
\text { Range }\end{array}$ & $\begin{array}{c}10.22 \pm 3.74 \\
3-19\end{array}$ & $\begin{array}{c}15.86 \pm 4.52 \\
6-25\end{array}$ & $\begin{array}{l}-- \\
--\end{array}$ & 6.262 & $<0.001 * *$ \\
\hline $\begin{array}{l}\text { Psoriatic arthritis } \\
\text { No } \\
\text { Yes }\end{array}$ & $\begin{array}{c}50(100.0 \%) \\
0(0.0 \%)\end{array}$ & $\begin{array}{c}41(82.0 \%) \\
9(18.0 \%)\end{array}$ & $\begin{array}{l}0(0.0 \%) \\
0(0.0 \%)\end{array}$ & 7.814 & $0.005^{*}$ \\
\hline $\begin{array}{l}\text { PASI score } \\
<10 \% \\
10-30 \% \\
30-50 \% \\
50-70 \% \\
\end{array}$ & $\begin{array}{c}17(34.0 \%) \\
33(66.0 \%) \\
0(0.0 \%) \\
0(0.0 \%) \\
\end{array}$ & $\begin{array}{c}0(0.0 \%) \\
7(14.0 \%) \\
42(84.0 \%) \\
1(2.0 \%) \\
\end{array}$ & $\begin{array}{l}17(17 \%) \\
40(40 \%) \\
42(42 \%) \\
1(1.0 \%)\end{array}$ & 76.90 & $<0.001 * *$ \\
\hline $\begin{array}{l}\text { High Sensitive C-rea } \\
\text { Average } \\
\text { High } \\
\text { Low }\end{array}$ & \begin{tabular}{|c|} 
tive protein \\
$26(52.0 \%)$ \\
$0(0.0 \%)$ \\
$24(48.0 \%)$
\end{tabular} & $\begin{array}{c}0(0.0 \%) \\
50(100.0 \%) \\
0(0.0 \%)\end{array}$ & $\begin{array}{l}0(0.0 \%) \\
0(0.0 \%) \\
0(0.0 \%)\end{array}$ & 100 & $<0.001 * *$ \\
\hline
\end{tabular}

t-Independent Sample t-test; ${ }^{\#} \chi^{2}$ : Chi-square, ${ }^{*}$ p-value $<0.05 \mathrm{~S} ; * *$ p-value $<0.001 \mathrm{HS}$.

This table shows statistically significant difference between sub-groups according to disease duration (years), psoriatic arthritis, PASI score and high Sensitive C-reactive protein.

Table (5): Comparison between sub-group Topical Treatment, Systemic Treatment and Control according to Echo data

\begin{tabular}{|c|c|c|c|c|c|}
\hline Echo & $\begin{array}{c}\text { Group Ia: } \\
(n=50)\end{array}$ & $\begin{array}{c}\text { Group Ib: } \\
(n=50)\end{array}$ & $\begin{array}{c}\text { Control } \\
(n=30)\end{array}$ & ANOVA & p-value \\
\hline $\begin{array}{l}\text { Aortic Dimensions }(\mathbf{m m}) \\
\text { Mean } \pm \text { SD } \\
\text { Range }\end{array}$ & $\begin{array}{c}25.42 \pm 2.18 \\
21-30\end{array}$ & $\begin{array}{c}26.62 \pm 2.87 \\
20-33\end{array}$ & $\begin{array}{c}27.80 \pm 3.74 \\
22-34\end{array}$ & 6.658 & $0.002 *$ \\
\hline $\begin{array}{l}\text { LA diameter }(\mathbf{m m}) \\
\text { Mean } \pm \text { SD } \\
\text { Range }\end{array}$ & $\begin{array}{c}32.74 \pm 2.58 \\
27-39\end{array}$ & $\begin{array}{c}34.42 \pm 2.75 \\
27-39\end{array}$ & \begin{tabular}{|c|}
$34.77 \pm 4.09$ \\
$27-41$
\end{tabular} & 5.540 & $0.005^{*}$ \\
\hline $\begin{array}{l}\text { LVEDD (mm) } \\
\text { Mean } \pm \text { SD } \\
\text { Range } \\
\end{array}$ & \begin{tabular}{|c}
$43.78 \pm 5.71$ \\
$33-56$ \\
\end{tabular} & $\begin{array}{c}47.60 \pm 5.45 \\
31-57 \\
\end{array}$ & \begin{tabular}{|c|}
$46.97 \pm 2.81$ \\
$41-51$ \\
\end{tabular} & 7.782 & $\begin{array}{c}<0.001 \\
* *\end{array}$ \\
\hline $\begin{array}{l}\text { LVESD }(\mathbf{m m}) \\
\text { Mean } \pm \text { SD } \\
\text { Range } \\
\end{array}$ & \begin{tabular}{|c}
$28.78 \pm 4.04$ \\
$20-38$ \\
\end{tabular} & $\begin{array}{c}31.44 \pm 3.63 \\
21-38 \\
\end{array}$ & \begin{tabular}{|c|}
$29.97 \pm 2.51$ \\
$26-35$ \\
\end{tabular} & 6.919 & $\begin{array}{c}<0.001 \\
* *\end{array}$ \\
\hline $\begin{array}{l}\text { LVED volume (ml) } \\
\text { Mean } \pm \text { SD } \\
\text { Range }\end{array}$ & $\mid \begin{array}{c}103.24 \pm 16.2 \\
65-140\end{array}$ & $\begin{array}{c}109.60 \pm 21.9 \\
60-145\end{array}$ & $\begin{array}{c}108.80 \pm 17.2 \\
80-145\end{array}$ & 1.620 & 0.202 \\
\hline $\begin{array}{l}\text { LVES volume }(\mathbf{m l}) \\
\text { Mean } \pm \text { SD } \\
\text { Range }\end{array}$ & \begin{tabular}{|c}
$47.26 \pm 8.44$ \\
$29-69$ \\
\end{tabular} & $\begin{array}{c}49.24 \pm 9.49 \\
29-68 \\
\end{array}$ & \begin{tabular}{|c|}
$47.27 \pm 8.48$ \\
$29-57$ \\
\end{tabular} & 0.765 & 0.467 \\
\hline $\begin{array}{l}\text { LV EF\% } \\
\text { Mean } \pm \text { SD } \\
\text { Range }\end{array}$ & \begin{tabular}{|c|}
$60.20 \pm 4.19$ \\
$54-75$ \\
\end{tabular} & $\begin{array}{c}57.76 \pm 1.92 \\
55-62 \\
\end{array}$ & $\begin{array}{c}62.40 \pm 3.12 \\
57-69 \\
\end{array}$ & 9.588 & $\begin{array}{c}<0.001 \\
* *\end{array}$ \\
\hline
\end{tabular}

F-One way analysis of variance; p-value $>0.05(\mathrm{NS}) ; *<0.05(\mathrm{~S}) ; * *<0.001(\mathrm{HS})$.

This table shows statistically significant difference between sub-groups according to Aortic Dimensions $(\mathrm{mm})$, Left atrial diameter $(\mathrm{mm}), \mathrm{LV}$ end-diastolic dimension $(\mathrm{mm}), \mathrm{LV}$ end-systolic dimension $(\mathrm{mm})$ and LV ejection fraction $\%$.

Table (6): Comparison between sub-group Topical Treatment, Systemic Treatment and Control according to speckle 


\begin{tabular}{|c|c|c|c|c|c|}
\hline Speckle & $\begin{array}{c}\text { Group Ia: } \\
(n=50)\end{array}$ & $\begin{array}{c}\text { Group Ib: } \\
(n=50)\end{array}$ & Control $(n=30)$ & ANOVA & p-value \\
\hline $\begin{array}{l}\text { Apical 3 chamber \% } \\
\text { Mean } \pm \text { SD } \\
\text { Range }\end{array}$ & $\begin{array}{c}-18.99 \pm 2.27 \\
-24--16\end{array}$ & $\begin{array}{c}-16.73 \pm 2.26 \\
-22--14\end{array}$ & $\begin{array}{c}-21.27 \pm 1.51 \\
-25--19\end{array}$ & 44.121 & $<0.001 * *$ \\
\hline $\begin{array}{l}\text { Apical } 4 \text { chamber \% } \\
\text { Mean } \pm \text { SD } \\
\text { Range }\end{array}$ & $\begin{array}{c}-19.71 \pm 2.31 \\
-24.1--15\end{array}$ & $\begin{array}{c}-17.38 \pm 2.23 \\
-23--14\end{array}$ & $\begin{array}{c}-22.00 \pm 1.41 \\
-24--20\end{array}$ & 46.358 & $<0.001 * *$ \\
\hline $\begin{array}{l}\text { Apical } 2 \text { chamber \% } \\
\text { Mean } \pm \text { SD } \\
\text { Range } \\
\end{array}$ & $\begin{array}{c}-18.94 \pm 2.43 \\
-23--13\end{array}$ & $\begin{array}{c}-16.54 \pm 2.80 \\
-23--11\end{array}$ & $\begin{array}{c}-21.47 \pm 1.41 \\
-24--19 \\
\end{array}$ & 40.434 & $<0.001 * *$ \\
\hline
\end{tabular}

F-One Way Analysis of Variance; **p-value <0.001 HS

This table shows statistically significant difference between sub-groups according to Apical 3 chamber\%, Apical 4 chamber\% and Apical 2 chamber\%.

Table (7): Correlation between LV GLSS\% with age, BMI, duration of disease and PASI score, using Pearson Correlation Coefficient.

\begin{tabular}{|l|c|c|}
\hline \multirow{2}{*}{ Baseline characteristics } & \multicolumn{2}{|c|}{ LV GLSS\% } \\
\cline { 2 - 3 } & $\mathbf{r}$ & p-value \\
\hline Age (years) & 0.770 & $<0.001^{* *}$ \\
\hline BMI [wt/(ht) 2 ] & 0.636 & $<0.001^{* *}$ \\
\hline Duration of Disease (years) & 0.814 & $<0.001^{* *}$ \\
\hline PASI score & 0.805 & $<0.001^{* *}$ \\
\hline
\end{tabular}

r-Pearson Correlation Coefficient, **p-value $<0.001 \mathrm{HS}$

Positive correlation and significant correlation between LV GLSS\% with Age (years), BMI [wt/(ht) ${ }^{2}$, Duration of Disease (years) and PASI score of patients group.

Table (8): Correlation between LV GLSS\% with Echo data, using Pearson Correlation Coefficient

\begin{tabular}{|l|c|c|}
\hline \multirow{2}{*}{ Echocardiography } & \multicolumn{2}{|c|}{ LV GLSS\% } \\
\cline { 2 - 3 } Echo & & p-value \\
\hline Aortic Dimensions (mm) & 0.131 & 0.194 \\
\hline Left atrial diameter (mm) & 0.353 & $<0.001^{* *}$ \\
\hline LV end-diastolic dimension (mm) & 0.269 & $0.007^{*}$ \\
\hline LV end-systolic dimension (mm) & 0.199 & $0.047^{*}$ \\
\hline LV end-diastolic volume (ml) & -0.153 & 0.129 \\
\hline LV end-systolic volume (ml) & -0.140 & 0.165 \\
\hline LV ejection fraction \% & -0.205 & $0.041^{*}$ \\
\hline Speckle & & \\
\hline Apical 3 chamber\% & 0.861 & $<0.001^{* *}$ \\
\hline Apical 4 chamber\% & 0.860 & $<0.001^{* *}$ \\
\hline Apical 2 chamber\% & 0.923 & $<0.001^{* *}$ \\
\hline
\end{tabular}

r-Pearson correlation coefficient, p-value $>0.05$ (NS); $*<0.05$ (S); $* *<0.001$ (HS)

Positive correlation and significant correlation between LV GLSS\% with Echo and speckle data of patients group.

\section{DISCUSSION}

Duration of the disease was ranged from 3 to 25 years with mean \pm SD of $13.04 \pm 5$ years in group (1), $10.22 \pm 3.74$ years in subgroup (1a) and $15.86 \pm 4.52$ years in subgroup (1b). Comparison between the two subgroups showed statistically highly significant difference $(\mathrm{P}<0.001)$.

Psoriatic arthritis was found in only $9 \%$ of the patients, they all were in the systemic treatment subgroup (1b), no arthritis was found in the subgroup (1a), they were statistically highly significant difference $(\mathrm{P}<0.001)$.
PASI score was $<10 \%$ in $17 \%, 10-30 \%$ in $40 \%$, $30-50 \%$ in $42 \%$ and $50-70 \%$ in only $1 \%$ of the studied psoriatic patients.

Previous studies revealed the association between the duration of psoriasis or its severity, as assessed by the PASI score, and the degree of the left ventricular systolic impairment ${ }^{(\mathbf{1 2})}$. Kotwica et al. ${ }^{(\mathbf{1 3})}$ confirmed this relationship only with respect to the latter. It is likely that the PASI score more accurately reflects the activity of pathophysiological derangements responsible for the myocardial function abnormalities 
than the duration of the disease, which sometimes is difficult to precisely determine.

High Sensitive C-reactive protein (Hs-CRP) was within average in $26 \%$ of the patients (all in the topically treated group), high in $50 \%$ of the patients (all in the systemic treated group) and low in $24 \%$ of the patients (all in the topically treated group). So, about half of our patients showed increase in Hs-CRP all of them were in the systemic treated subgroup. There are statistically highly significant differences between the two patient subgroups.

Parallel to our study, Shang et al. ${ }^{(14)}$ found correlations between the LV end- systolic dimension and hs- CRP. The pathogenesis of these psoriatic arthritis (PsA)- related effects on LV structure was not fully explained in this study; however, the authors proposed that chronic systemic inflammation may represent a possible cause of adverse LV remodeling.

Echocardiography of the present study showed that the mean arterial dimension was $26.02 \pm 2.61 \mathrm{~mm}$ and $27.80 \pm 3.74 \mathrm{~mm}$ in the patients and control groups, respectively. The mean left atrial diameter was $33.58 \pm$ $2.78 \mathrm{~mm}$ and $34.77 \pm 4.09 \mathrm{~mm}$ in the patients and control groups, respectively. The mean LVEDD was $45.69 \pm 5.88 \mathrm{~mm}$ and $46.97 \pm 2.81 \mathrm{~mm}$ in the patients and control groups, respectively. The mean LVESD was $30.11 \pm 4.05 \mathrm{~mm}$ and $29.97 \pm 2.51 \mathrm{~mm}$ in the patients and control groups, respectively. The mean LVED volume was $106.42 \pm 19.4 \mathrm{ml}$ and $108.8 \pm 17.19$ $\mathrm{mm}$ in the patients and control groups, respectively. The mean LVES volume was $48.25 \pm 8.99 \mathrm{ml}$ and $47.27 \pm 8.48 \mathrm{ml}$ in the patients and control groups, respectively. The mean LV EF \% was $58.99 \pm 3.48$ and $62.40 \pm 3.12$ in the patients and control groups, respectively. Aortic Dimensions, LA diameter and EF $\%$ showed statistically significant difference $(\mathrm{P}<0.05)$, the other parameters was not significant $(\mathrm{P}>0.05)$.

Coincides with our results Bülbül $\boldsymbol{e t} \boldsymbol{a l} .{ }^{(9)}$ found no differences in LV diameter, EF, left atrium diameter, and LV mass (LVM) index between subjects with and without psoriasis. However, in patients with psoriasis, diastolic dysfunctions were detected more frequently. Additionally, LV strain and all SR values were found to be significantly lower in patients with psoriasis than in control subjects.

Two-dimension Speckle showed that the mean Apical 3 chamber $\%$ was $-17.86 \pm 2.52$ and $-21.27 \pm 1.51$, in the patients and control groups, respectively. The means were $18.99 \pm 2.27$ and $-16.73 \pm 2.26$ in subgroups $1 \mathrm{a} \& 1 \mathrm{~b}$, respectively. The mean Apical 4 chamber \% was $18.54 \pm 2.54$ and $-22.00 \pm 1.41$ in the patients and control groups, respectively. The means were $-19.71 \pm$ 2.31 and $-17.38 \pm 2.23$ in subgroups $1 \mathrm{a} \& 1 \mathrm{~b}$, respectively. The mean Apical 2 chamber \% was $17.74 \pm 2.87$ and $-21.47 \pm 1.41$ in the patients and control groups, respectively. The means were $-18.94 \pm$ 2.43 and $-16.54 \pm 2.8$ in subgroups $1 \mathrm{a} \& 1 \mathrm{~b}$, respectively. They all showed statistically highly significant difference $(\mathrm{P}<0.001)$.

Several studies carried out in the last decade have reported various echocardiographic findings in relation to systolic function parameters in psoriasis patients. Guven et al. ${ }^{(\mathbf{1 5})}$ reported comparable LV dimensions, wall thickness, and EF between psoriasis and healthy subjects.

However, using the speckle strain echocardiography in patients with psoriasis they demonstrated significantly changed myocardial deformation markers: transversal and longitudinal deformation. These markers were significantly correlated with an increased parathormone $(\mathrm{PTH})$ concentration in blood. Observed markers alterations were not correlated with brain natriuretic peptide (BNP) concentration in blood, which was similar in patients with psoriasis and in control group ${ }^{(\mathbf{1 6})}$.

Saricaoglu et al. ${ }^{(17)}$ investigated 21 PsA patients with LV EF of $>50 \%$ and reported increased LV enddiastolic and end- systolic diameters compared with those in control subjects. However, Ardic et al. ${ }^{(\mathbf{1 8})}$ showed no difference in LV diameters or EF between patients with psoriasis and healthy controls.

Biyik et al. ${ }^{(19)}$ reported that LV hypertrophy, LV diastolic dysfunction, LV wall motion abnormalities, and mitral valve and tricuspid valve prolapse were more frequent in patients with psoriasis compared with control subjects.

Additionally, in a study by Shang et al. ${ }^{(14)}$ the comprehensive evaluation of LV systolic and diastolic function by conventional echocardiography and TDI revealed a high prevalence of subclinical LV dysfunction in patients with PsA, even in those without traditional $\mathrm{CV}$ risk factors. These authors found no differences in LV diameter, EF, left atrium diameter, or LVM index; however, diastolic dysfunction was detected more frequently in patients with PsA and LV strain, and all SR values were found to be significantly lower in patients with PsA than in control subjects.

Speckle tracking echocardiography has been demonstrated to be superior to conventional imaging in deformation imaging. The superiority of 2- D strain imaging over TDI and Doppler strain imaging in the assessment of LV regional and global functions has been shown in a number of studies, such as in ischemic/non- ischemic cardiomyopathy and hypertrophic cardiomyopathy. However, no 2- D strain imaging studies related to psoriasis have been reported in the literature ${ }^{(\mathbf{2 0})}$.

Comparison between patients and control according to LV GLSS\% showed that the mean values were $-17.97 \pm 2.46$ and $-21.67 \pm 1.18$ in the patients and control groups, respectively. They showed highly 
statistically significant difference between the two groups according to LV GLSS\%. The mean values of the patient subgroups were $-19.18 \pm 2.15$ and $-16.76 \pm$ 2.16 in subgroup 1a and $1 \mathrm{~b}$, respectively. They showed a statistically highly significant difference $(\mathrm{P}<0.001)$.

Ikonomidis et al. ${ }^{(\mathbf{2 1})}$ stated that impaired arterial elastic properties, coronary microcirculatory dysfunction and excess inflammatory and oxidative stress burden were associated with impaired LV longitudinal deformation in psoriatic patients.

A correlation coefficient (r) between LV GLSS\% with age, BMI, duration of disease and PASI score were $0.770,0.636,0.814$ and 0.805 , respectively. They were statistically highly significant difference. A correlation coefficient (r) between LV GLSS\% with speckle Echo data, using Pearson Correlation Coefficient were $0.861,0.860$, and 0.923 corresponding to Apical 3 chamber \%, Apical 4 chamber $\%$ and Apical 2 chamber \%, respectively. They showed a statistically highly significant difference $(\mathrm{P}<0.001)$.

The current study demonstrated that left ventricular longitudinal deformation is decreased in patients with psoriasis and this subclinical systolic impairment is associated with immunologic activation, with the increased galectin-3 (Gal-3) acting as a mediator of this relationship. These findings suggest that pro-inflammatory up-regulation in psoriasis may be responsible for the stimulation of myocardial fibrosis leading to LV functional derangements. This was confirmed by Kotwica $\boldsymbol{e t}$ al. ${ }^{(\mathbf{1 3 )})}$ who added that a growing body of evidence from epidemiologic and pathophysiologic studies indicates that psoriasis should be considered not only as one of the inflammatory skin disorders, but also as a systemic disease with increased incidence of the wellestablished factors of cardio-vascular risk.

The pro-fibrotic activity of Gal-3 includes stimulation of the proliferation and transformation of myocardial fibroblasts, with a subsequent increase in the formation and accumulation of collagen within the interstitium and perivascular space 37. These changes may lead to left ventricular systolic and diastolic dysfunction, which is initially subclinical, but unless diagnosed and treated appropriately, it can progress in time to an overt heart failure ${ }^{(\mathbf{1 3})}$.

The investigations of Kotwica et al. ${ }^{(\mathbf{1 3 )})}$ showed an increased concentration of serum Gal-3 in psoriatic patients, as well as an inverse association between GLS and Gal-3, and a progressive deterioration of GLS across the Gal-3 tertiles, both of which might suggest a role for this lectin in the development of cardiac dysfunction in psoriasis. This notion has been further reinforced by the results of stepwise multiple regression analysis, which revealed that left ventricular longitudinal myocardial deformation in psoriatic patients was independently predicted by Gal-3 and ESR. The mediation analysis showed that the effect of ESR on GLS was in part mediated by Gal-3. This is consistent with the pathophysiological role of Gal-3, as well as with the recognized mechanisms promoting its release.

Ikonomidis et $\boldsymbol{a l} .{ }^{(21)}$ demonstrated relationship between depressed GLS and increased blood interleukin-6 in psoriatic patients. Conversely, our work does not provide any clinical evidence supporting the postulated involvement of Gal-3 in the interleukin6 and neutrophil-mediated thrombotic mechanisms ${ }^{(22)}$.

In Bülbül et $\boldsymbol{a l} .{ }^{(9)}$ study, LV dysfunction was correlated with duration of disease. Patients with longer duration of disease may be at greater risk for flares than those with a short duration of disease, and thus inflammatory damage may be higher in these patients. This may explain why a long duration of disease was found to be associated with $\mathrm{LV}$ dysfunction. Another possible mechanism for the relationship between subclinical impairment of LV function and psoriasis is diastolic dysfunction. Diastolic dysfunction may be considered as a cause of subclinical impairment of LV function in patients with psoriasis. In the present study, we detected diastolic dysfunction in $37.5 \%$ of psoriasis patients. In previous studies, myocardial systolic and diastolic function in diastolic heart failure was characterized using conventional echocardiography and TDI, which reported subclinical myocardial systolic dysfunction in diastolic heart failure.

Echocardiographic evaluation revealed an increased prevalence of diastolic dysfunction in psoriatic patients compared to control population. Diastolic dysfunction, prevalently represented by abnormalities of early to late ventricular filling velocities ratio (E/A), early flow deceleration time (DT) and isovolumic relaxation time (IVRT), may be the first abnormality in heart disease, which involve not only the left, but also the right ventricle (MPI, E/A) (23).

\section{CONCLUSIONS}

The 2- D strain method appears to be useful in the detection of LV systolic dysfunction in patients with psoriasis. Subclinical left ventricular systolic dysfunction in psoriasis is linked with the inflammatory upregulation, and enhanced pro-fibrotic activity may be involved in this process. These putative mechanisms may be responsible for the observed higher incidence of heart failure in this disease condition and should be considered as a potential target for preventive and therapeutic measures.

\section{REFERENCES}


1. Lin HW, Wang KH, Lin HC (2011): Increased risk of acute myocardial infarction in patients with psoriasis: a 5- year population- based study in Taiwan. J Am Acad Dermatol., 64: 495- 501.

2. Karadag AS, Yavuz B, Ertugrul DT et al. (2010): Is psoriasis a pre- atherosclerotic disease? Increased insulin resistance and impaired endothelial function in patients with psoriasis. Int J Dermatol., 49: 642- 646.

3. Siegel D, Devaraj S, Mitra A et al. (2013): Inflammation, atherosclerosis, and psoriasis. Clin Rev Allergy Immunol., 44(2): 194-204.

4. Shiraki K, Satoh H, Saitoh T et al. (2010): Comparison of global and regional abnormalities in $99 \mathrm{mTc}-$ sestamibi and cardiac magnetic resonance imaging in dilated cardiomyopathy. J Card Fail., 16: 641- 648.

5. Ahlehoff O, Hansen PR, Gislason GH et al. (2016): Myocardial function and effects of biologic therapy in patients with severe psoriasis: a prospective echocardiographic study. J Eur Acad Dermatol Venereol., 30: 819-23.

6. Choi BG, Kim MJ, Yang HS et al. (2017): Assessment of arterial stiffness in Korean patients with psoriasis by cardio-ankle vascular index. Angiology, 68(7): 608-613.

7. Hansen PR, Juhl CR, Isaksen JL et al. (2018): Frequency of Electrocardiographic Abnormalities in Patients With Psoriasis. Am J Cardiol., 121(8): 10041007.

8. Dandel $M$ and Hetzer $R$ (2009): Echocardiographic strain and strain rate imaging - clinical applications. Int J Cardiol., 132: 11-24.

9. BülbülŞen B, Ekiz Ö, Rifaioğlu EN et al. (2016): Assessment of subclinical left ventricular dysfunction in patients with psoriasis by speckle tracking echocardiography: A Speckle Tracking Study. Int J Dermatol., 55(2):158-64.

10. Lang RM, Badano LP, Mor-Avi, V, Afilalo J, Armstrong A, Ernande $\mathrm{L}$ et al. (2015): Recommendations for Cardiac Chamber Quantification by Echocardiography in Adults: An Update from the American Society of Echocardiography and the European Association of Cardiovascular Imaging. European Heart Journal - Cardiovascular Imaging, 16(3): 233-271.

11. Kocabay G, Muraru D, Peluso D et al. (2014): Normal left ventricular mechanics by two- dimensional speckle tracking echocardiography. Reference values in healthy adults. Rev Esp Cardiol. (Engl Ed), 67:651- 658.
12. Altun B, Bulucu F, Demirbas S et al. (2013): The relationship between some of the cardiovascular risk factors and arterial stiffness parameters in essentially hypertensive patients. Clin Exp Hypertens., 35(6): 444 448.

13. Kotwica T, Relewicz J, Rojek A et al. (2019): Role of galectin-3 in subclinical myocardial impairment in psoriasis. J Eur Acad Dermatol Venereol., 33(1):136142.

14. Shang Q, Tam LS, Yip GW et al. (2011): High prevalence of subclinical left ventricular dysfunction in patients with psoriatic arthritis. J Rheumatol., 38: 13631370.

15. Guven ASS, Aksu E, Caglayan CE (2003): Echocardiographic evaluation in patients with psoriasis. T Klin J Cardiol., 16: 77-81.

16. Milaniuk S, Pietrzak A, Mosiewicz B et al. (2015): Influence of psoriasis on circulatory system function assessed in echocardiography. Arch Dermatol Res., 307(10):855-61.

17. Saricaoglu H, Gullulu S, Bulbul Baskan E et al. (2003): Echocardio-graphic findings in subjects with psoriatic arthropathy. J Eur Acad Dermatol Venereol., 17: 414-417.

18. Ardic I, Kaya MG, Yarlioglues M et al. (2010): Impaired aortic elastic properties in normotensive patients with psoriasis. Blood Press., 19: 351-358.

19. Biyik I, Narin A, Bozok MA et al. (2006): Echocardiographic and clinical abnormalities in patients with psoriasis. J Int Med Res., 34: 632-639.

20. Popovic ZB, Kwon DH, Mishra M et al. (2008): Association between regional ventricular function and myocardial fibrosis in hypertrophic cardiomyopathy assessed by speckle tracking echocardiography and delayed hyperenhancement magnetic resonance imaging. J Am Soc Echocardiogr., 21: 1299-1305.

21. Ikonomidis I, Makavos G, Papadavid E et al. (2015): Similarities in coronary function and myocardial deformation between psoriasis and coronary artery disease: the role of oxidative stress and inflammation. Can J Cardiol., 31:287-95.

22. DeRoo EP, Wrobleski SK, Shea EM et al. (2015): The role of galectin-3 and galectin-3-binding protein in venous thrombosis. Blood, 125:1813-21.

23. Gorga E, Scodro M, Valentini et al. (2018): Echocardiographic evaluation of diastolic dysfunction in young and healthy patients with psoriasis: A case-control study. Monaldi Arch Chest Dis., 88(3):934. 